Plant Tissue Cult. \& Biotech. 21(1): 53-61, 2011 (June)

$\overline{\text { PTC\&B }}$

\title{
Bacteria Associated with the Tannery Effluent and their
} Alkaline Protease Activities

\section{Mihir Lal Saha*, K. J. M. Hashina Begum, Mahbubar Rahman Khan and Donald James Gomes ${ }^{1}$}

Laboratory of Microbiology, Department of Botany, University of Dhaka, Dhaka-1000, Bangladesh

Key words: Bacteria, tannery, effluent, alkaline protease

\begin{abstract}
Samples collected from different stages of the tannery processing were found to be alkaline. A good number of bacteria were found to be associated with the different stages of leather processing. The aerobic heterotrophic bacterial count ranged in between $11.9 \times 10^{6}$ and $46.7 \times 10^{6}$. The highest count was observed in the soaking stage and the minimum was found with the bating stage. Among 40 isolates, 31 showed positive proteolytic activities on different protein based media. Identified organisms were Bacillus subtilis (9), B. licheniformis (6), B. alcalophilus (2), B. badius (2), B. cereus (2), B. circulans (2), B. pumilus (2), B. alvei (1), B. brevis (1), B. coagulans (1), B. megaterium (1), B. polymyxa (1) and Micrococcus varians (1). Proteolytic activity was measured as zone ratio on skim milk agar which was found to be in between 1.5 and 5.8. Higher zone ratio was observed in B. subtilis (TS/1/E), B. pumilus (TS/1/S1/A3 and TD/S2/C3), B. licheniformis (TS/1/Q) and $B$. badius (TD/21-D). The alkaline protease production by the nine selected isolates ranged in between 7.1 and $119.3 \mathrm{U} / \mathrm{ml}$. Two isolates of B. pumilus (TS/1/S1/A3 and TD/S2/C3) were found to be good alkaline protease producers (119.3 and $94.8 \mathrm{U} / \mathrm{ml}$ ) among the tested organisms. Biotechnologically these two isolates or their enzymes could be utilized in the tannery industry.
\end{abstract}

\section{Introduction}

Environmental pollution is a global concern and scientists all over the world are working on its possible impacts and remedies to save our planet. In the tannery industry the raw hide has to undergo a series of chemical treatments before it turns into flattering leather. This includes soaking, liming, dehairing, deliming, bating, degreasing etc. Wastes arising from surplus or washed-out chemicals are

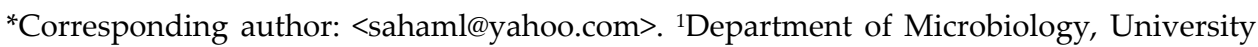
of Dhaka, Dhaka-1000, Bangladesh. 
quite toxic. Spent liquors belonging to soaking, dehairing are discharged intermittently without controlled legislation and increase the environmental pollution. Some tanneries have been forced to close down due to their pressure on environmental pollution (Davighi 1988).

For the interaction between bacteria and leather processing, information is required on the types of bacteria found in effluents of the leather processing industries. Among microbial enzymes having industrial applications, proteases are one group of the most important enzymes (Aunstrup 1979). In a study Hossain et al. (2004) reported extracellular protease production from Planococcus citreus. Alkaline proteases are the important proteases used in laundry detergents and leather processing (Chu et al. 1992). Genckal and Tari (2006) isolated alkaline protease producing Bacillus strains from extreme alakaline conditions from Izmir, Turkey. Bangladesh and other South Asian countries produce and export leather as one of the major items which are mostly being processed by chemical treatment, resulting in inferior quality of products as well as pollution. Enzymatic depilation has been well accepted as an alternative to the chemical process. Use of alkaline protease in leather processing can help to solve the above mentioned problems. The enzymatic dehairing and bating of hide have been widely accepted as a safe and sound alternative to the chemical process (Manachini et al. 1988). Microorganisms are being used as a tool for production of biochemical and biologically active compounds mainly because of their abundant growth, higher productivity and lower cost of production. Tannery industry is one of the major industries of Bangladesh. Effluent from leather processing industries might give us a good source of proteolytic microorganisms. Therefore, the present study was undertaken to isolate and identify bacteria from tannery industries and to screen out some potential proteolytic bacteria for leather processing purpose.

\section{Materials and Methods}

Hazaribagh tannery industries of Dhaka Metropolitan City, Bangladesh were selected for the present study. Samples were collected from the four selected stages viz. soaking, liming, deliming and bating. Sample waters were collected in sterile plastic bottles sterilized with alcohol. The $\mathrm{pH}$ of the collected samples was measured in the laboratory by a pH meter (Jenway $3310 \mathrm{pH}$ meter, U.K.).

Nutrient agar (NA) and peptone yeast extract agar (PYG) media were used for the enumeration and isolation of aerobic heterotrophic bacteria present in samples. The $\mathrm{pH}$ of the medium was adjusted to 7.2. Enumeration and isolation of aerobic heterotrophic bacteria were carried out by two different techniques viz. serial dilution technique (Greenberg et al. 1980) and spread plate technique (Sharp and Lyles (1969). The inoculated plates were inverted and incubated at 
$37^{\circ} \mathrm{C}$ for $24 \mathrm{hrs}$ in an incubator (Memmert $\mathrm{GmbH}+\mathrm{Co} \mathrm{Kg} 8540$ Sehwabach). After $24 \mathrm{hrs}$ of incubation the plates having well discrete colonies were selected for counting. Using colony counter (Digital colony counter, DC-8 OSK 100086, Kayagaki, Japan) the developed colonies were counted. For provisional identification of the isolates important biochemical tests were carried out viz. carbohydrate fermentation, arginine hydrolysis, catalase, deep glucose agar, tyrosine degradation, egg-yolk lecithinase, casein hydrolysis, protease, gelatin hydrolysis, starch hydrolysis, methyl red, nitrate reduction, citrate utilization, oxidase, urease etc. Following Bergey's Manual (Sneath et al. 1986), Microbiological Methods (Collins and Lyne 1984), Laboratory Manual for General Microbiology (Eklund and Lankford 1967), Laboratory Manual for General Bacteriology (Peltier et al. 1959) and Pure Culture of Bacteria (Bryan 1950) physiological and biochemical studies were carried out for identification.

Protease activity was determined by the zone ratio on skim milk agar. To determine the zone ratio $1 \mathrm{ml}$ of sterilized milk was mixed with nutrient agar in sterilized Petri plate and allowed to solidify. Each of the isolates was point inoculated on skim milk agar (SMA) plate using sterilize straight needle and incubated at $37^{\circ} \mathrm{C}$ for $24 \mathrm{hrs}$. The isolates forming clear zone around the colonies were determined by $\mathrm{mm}$ scale. The following formula was used to determine the zone ratio.

$$
\text { Zone ratio }=\frac{\text { Zone diameter }(\mathrm{mm})}{\text { Colony diameter }(\mathrm{mm})}
$$

Alkaline protease producing broth (APPB) (Horikoshi 1971a) medium was used to determine protease activity. This medium consisted of $1 \%$ glucose, $0.5 \%$ peptone, $0.5 \%$ yeast extract, $0.1 \% \mathrm{~K}_{2} \mathrm{HPO}_{4}, 0.01 \% \mathrm{MgSO}_{4} \cdot 7 \mathrm{H}_{2} \mathrm{O}$ and $1 \% \mathrm{Na}_{2} \mathrm{CO}_{3}$ and $\mathrm{pH}$ of the medium was adjusted to 6.0 with acetic acid. To prepare seed culture, test tube containing $10 \mathrm{ml}$ APPB medium was inoculated with one loopful inoculum from fresh slant culture. After proper mixing the test tubes were incubated at $37^{\circ} \mathrm{C}$ for $24 \mathrm{hrs}$ in an orbital shaker incubator (Gallenkemp Orbital Shaker, Germany) at $120 \mathrm{rpm}$. Ten $\mathrm{ml}$ of seed culture was transferred aseptically to a conical flask containing $40 \mathrm{ml}$ of medium. All the flasks were incubated in orbital shaker incubator at $37^{\circ} \mathrm{C}$ for $72 \mathrm{hrs}$ at $120 \mathrm{rpm}$. Crude enzymes were separated from the fermentation broth by refrigerated centrifugation (WIFUG Lab Centrifuge, 2000 Germany) at $4000 \mathrm{rpm}$ for $20 \mathrm{~min}$ and supernatant was collected and used for enzyme assay.

Protease assay was determined by azocasein digest method (Kreger and Lockwood 1981). In this method $400 \mu \mathrm{l}$ of $1.6 \%$ azocasein solution in $0.5 \mathrm{M}$ Tris$\mathrm{HCl}$ buffer at $\mathrm{pH} 8.5$ was incubated with $800 \mu \mathrm{l}$ crude enzyme for $30 \mathrm{~min}$ at $40^{\circ} \mathrm{C}$ in a water bath with shaking. The reaction was stopped by the addition of $2.8 \mathrm{ml}$ of $5 \%$ trichloroacetic acid (TCA) following by holding the mixture for $30 \mathrm{~min}$ at 
$4^{\circ} \mathrm{C}$. After centrifugation at $4000 \mathrm{rpm}$ for $20 \mathrm{~min} 2 \mathrm{ml}$ of supernatant was mixed with $2 \mathrm{ml}$ of $0.5 \mathrm{~N} \mathrm{NaOH}$ and the absorbance was read by a spectrophotometer (Spectronic ${ }^{\circledR} 20$ GenesysTM, USA) at $440 \mathrm{~nm}$. The control was prepared by adding TCA before the addition of crude enzyme. One unit of protease activity was defined as the amount of enzyme that produced an increase in absorbance of 0.01 under the above assay condition.

\section{Results and Discussion}

Bacterial count, colour and $\mathrm{pH}$ of the samples collected from different stages of leather processing were shown in the Table 1 . The aerobic heterotrophic bacterial count of the collected samples ranged in between $11.9 \times 10^{6}$ and $46.7 \times 10^{6}$. The highest count was observed in the sample collected from the soaking stage and the minimum was found with the bating stage. Both NA and PYG were found to be good media for isolation of aerobic heterotrophic bacteria from the different stages of leather processing industries. The result clearly showed that a good number of bacteria were associated with the samples of different stages of leather processing unit. Colour of the samples varied with their sources. Collected samples were found to be alkaline $(\mathrm{pH}$ range 8.3 - 13.2). From four different samples 40 bacterial isolates were isolated. Out of 40 isolates 31 showed positive proteolytic activities on coagulated egg albumin, alkaline egg albumin, gelatin and casein (Data not shown).

Table 1. Colour, $\mathrm{pH}$ and bacterial load $(\mathrm{cfu} / \mathrm{ml})$ of the samples of different leather processing stages.

\begin{tabular}{llcccc}
\hline $\begin{array}{l}\text { Leather } \\
\text { processing stage }\end{array}$ & $\begin{array}{l}\text { Sample } \\
\text { colour }\end{array}$ & $\begin{array}{c}\text { Sample } \\
\mathrm{pH}\end{array}$ & $\begin{array}{c}\text { Bacterial } \\
\text { count on NA }\end{array}$ & $\begin{array}{c}\text { Bacterial count } \\
\text { on PYG }\end{array}$ & $\begin{array}{c}\text { Average } \\
\text { bacteria }\end{array}$ \\
\hline Soaking & Reddish & 9.9 & $71.8 \times 10^{6}$ & $21.5 \times 10^{6}$ & $46.7 \times 10^{6}$ \\
Liming & Gray & 13.2 & $18.1 \times 10^{6}$ & $12.3 \times 10^{6}$ & $15.2 \times 10^{6}$ \\
Deliming & Ash & 9.2 & $58.1 \times 10^{6}$ & $28.2 \times 10^{6}$ & $43.2 \times 10^{6}$ \\
Bating & Yellowish & 8.3 & $11.2 \times 10^{6}$ & $12.5 \times 10^{6}$ & $11.9 \times 10^{6}$ \\
\hline
\end{tabular}

NA = Nutrient agar; PYG = Peptone yeast extract agar.

Except one isolate (TS/1/D) all were found to be Gram positive spore former. The isolate TS/1/D was found to be a coccus and non spore former. All the isolates were aerobic and catalase positive. Some of the major biochemical tests were shown in the Table 2. By evaluating all the available morphological, microscopic and biochemical characteristics the isolated strains were provisionally identified according to the Bergeys Manual (Sneath et al. 1986). Except one (Micrococcus varians), all isolates belonged to the genus Bacillus. Under the Bacillus there were 12 distinct species viz. Bacillus subtilis (9), B. licheniformis (6), B. alcalophilus (2), B. badius (2), B. cereus (2), B. circulans (2), B. 
pumilus (2), B. alvei (1), B. brevis (1), B. coagulans (1), B. megaterium (1) and B. polymyxa (1). B. subtilis (9) and B. licheniformis (6) were found to be dominating over other species of Bacillus.

Table 2. Provisional identification of the bacteria isolated from different stages of leather processing.

\begin{tabular}{|c|c|c|c|c|c|c|c|c|c|}
\hline \multirow{2}{*}{$\begin{array}{l}\text { Sample } \\
\text { source }\end{array}$} & \multirow{2}{*}{$\begin{array}{c}\text { Isolate } \\
\text { No. }\end{array}$} & \multicolumn{7}{|c|}{ Biochemical profile } & \multirow{2}{*}{$\begin{array}{c}\text { Provisionally } \\
\text { identified bacteria }\end{array}$} \\
\hline & & $\mathrm{VP}$ & $\mathrm{MR}$ & Cit & $\mathrm{NO}_{3}$ & Cas & Oxi & Lev & \\
\hline \multirow{4}{*}{ Bating } & $\mathrm{TB} / 1 / \mathrm{B} 4$ & + & - & + & + & + & + & + & Bacillus subtilis \\
\hline & $\mathrm{TB} / 1 / 3$ & - & - & + & + & + & + & + & B. subtilis \\
\hline & $\mathrm{TB} / 1 / 10$ & - & - & + & + & + & + & + & B. circulans \\
\hline & $\mathrm{TB} / 1 / 8$ & + & - & + & + & + & + & + & B. subtilis \\
\hline \multirow{7}{*}{ Liming } & TL1/L8 & - & - & - & + & + & + & - & Bacillus badius \\
\hline & TL/1/L9 & - & - & - & + & + & + & - & B. cereus \\
\hline & TL/1/L/L2 & - & - & + & + & + & + & + & B. subtilis \\
\hline & $\mathrm{TL} / 1 / \mathrm{L} / \mathrm{L} 3$ & - & - & + & + & + & + & + & B. subtilis \\
\hline & $\mathrm{TL} / 1 / \mathrm{L} / \mathrm{L} 4$ & + & - & + & + & + & - & + & B. licheniformis \\
\hline & TL/1/L/L5 & + & - & - & + & + & + & - & B. alcalophilus \\
\hline & TL/21-L0 & + & - & + & + & + & + & + & B. brevis \\
\hline \multirow{13}{*}{ Soaking } & $\mathrm{TS} / 1 / \mathrm{S}-2$ & - & - & + & + & + & + & + & Bacillus licheniformis \\
\hline & $\mathrm{TS} / 1 / \mathrm{E}$ & - & - & + & + & + & + & + & B. subtilis \\
\hline & $\mathrm{TS} / 1 / \mathrm{H}$ & - & - & + & + & + & + & + & B. licheniformis \\
\hline & $\mathrm{TS} / 1 / \mathrm{O}$ & - & - & + & + & + & + & + & B. licheniformis \\
\hline & TS/1/S1/A3 & + & - & + & - & + & + & - & B. pumilus \\
\hline & $\mathrm{TS} / 1 / \mathrm{C}$ & + & - & + & + & + & + & + & B. subitilis \\
\hline & $\mathrm{TS} / 1 / \mathrm{G}$ & + & - & + & + & + & + & + & B. subtilis \\
\hline & TS/1/S1/PS3 & - & - & + & + & + & + & + & B. subtilis \\
\hline & $\mathrm{TS} / 1 / \mathrm{J}$ & - & - & - & + & + & + & - & B. coagulans \\
\hline & $\mathrm{TS} / 1 / \mathrm{P}$ & - & - & + & + & + & + & + & B. circulans \\
\hline & $\mathrm{TS} / 1 / \mathrm{S} 1 / \mathrm{P} 1$ & + & - & - & + & + & + & - & B. polymyxa \\
\hline & $\mathrm{TS} / 1 / \mathrm{Q}$ & - & - & + & + & + & + & + & B. licheniformis \\
\hline & $\mathrm{TS} / 1 / \mathrm{D}$ & - & - & - & + & + & - & - & Micrococcus varians \\
\hline \multirow{7}{*}{ Deliming } & TD/ S2/B1 & + & - & - & + & + & + & - & Bacillus megaterium \\
\hline & $\mathrm{TD} / \mathrm{S} 2 / \mathrm{C} 3$ & + & - & + & - & + & + & + & B. pumilus \\
\hline & $\mathrm{TD} / 21-\mathrm{D}$ & - & - & - & + & + & + & - & B. badius \\
\hline & TD/21-D0 & - & - & - & + & + & + & - & B. alcalophilus \\
\hline & TD/21-D1 & - & - & + & + & + & + & - & B. cereus \\
\hline & TD/21-D3 & - & - & + & - & + & + & + & B. licheniformis \\
\hline & $\mathrm{TD} / 21-\mathrm{D} 8$ & + & - & + & - & + & + & + & B. alvei \\
\hline
\end{tabular}

VP = Voges Proskauer; $\mathrm{MR}=$ Methyl red; $\mathrm{Cit}=$ Citrate, Cas $=$ Casein, Oxi $=$ Oxidase, Lev = Levan, + for Positive, - for Negative result. 
Protease activity on skim milk agar is shown in the Table 3. All the selected bacterial isolates showed positive protease activities on milk protein (casein) with the zone ratio ranged in between 1.5 and 5.8. Zone ratio 5 and more than 5 was observed in B. subtilis (TS/1/E), B. pumilus (TS/1/S1/A3 and TD/S2/C3), B. licheniformis (TS/1/Q) and B. badius (TD/21-D). The highest zone ratio was observed in two isolates of B. pumilus (TS/1/S1/A3 and TD/S2/C3). These two isolates were isolated from soaking and deliming stages. Nowadays enzyme finds huge application in various industries. In tannery alkaline protease has been

Table 3. Observation of protease activity as zone ratio observed on skim milk agar medium.

\begin{tabular}{|c|c|c|c|c|}
\hline $\begin{array}{l}\text { Isolate } \\
\text { No. }\end{array}$ & $\begin{array}{l}\text { Identified } \\
\text { bacteria }\end{array}$ & $\begin{array}{l}\text { Zone diameter } \\
(\mathrm{mm})\end{array}$ & $\begin{array}{c}\text { Colony } \\
\text { diameter }(\mathrm{mm})\end{array}$ & $\begin{array}{l}\text { Zone } \\
\text { ratio }\end{array}$ \\
\hline TB/1/B4 & Bacillus subtilis & 20 & 5 & 4.0 \\
\hline $\mathrm{TB} / 1 / 3$ & B. subtilis & 27 & 9 & 3.0 \\
\hline $\mathrm{TB} / 1 / 10$ & B. circulans & 20 & 5 & 4.0 \\
\hline $\mathrm{TB} / 1 / 8$ & B. subtilis & 25 & 9 & 2.8 \\
\hline TL1/L8 & B. badius & 33 & 13 & 2.5 \\
\hline TL/1/L9 & B. cereus & 37 & 25 & 1.5 \\
\hline $\mathrm{TL} / 1 / \mathrm{L} / \mathrm{L} 2$ & B. subtilis & 30 & 10 & 3.0 \\
\hline $\mathrm{TL} / 1 / \mathrm{L} / \mathrm{L} 3$ & B. subtilis & 22 & 5 & 4.4 \\
\hline $\mathrm{TL} / 1 / \mathrm{L} / \mathrm{L} 4$ & B. licheniformis & 22 & 6 & 3.6 \\
\hline TL/1/L/L5 & B. alcalophilus & 23 & 6 & 2.3 \\
\hline TL/21-L0 & B. brevis & 24 & 6 & 3.7 \\
\hline $\mathrm{TS} / 1 / \mathrm{S}-2$ & B. licheniformis & 27 & 15 & 1.8 \\
\hline $\mathrm{TS} / 1 / \mathrm{E}$ & B. subtilis & 25 & 5 & 5.0 \\
\hline $\mathrm{TS} / 1 / \mathrm{H}$ & B. licheniformis & 26 & 8 & 3.3 \\
\hline $\mathrm{TS} / 1 / \mathrm{O}$ & B. licheniformis & 27 & 7 & 3.9 \\
\hline TS/1/S1/A3 & B. pumilus & 46 & 8 & 5.8 \\
\hline $\mathrm{TS} / 1 / \mathrm{C}$ & B. subitilis & 23 & 7 & 3.2 \\
\hline $\mathrm{TS} / 1 / \mathrm{G}$ & B. subtilis & 24 & 8 & 3.0 \\
\hline TS/1/S1/PS3 & B. subtilis & 16 & 4 & 4.0 \\
\hline $\mathrm{TS} / 1 / \mathrm{J}$ & B. coagulans & 29 & 15 & 1.9 \\
\hline $\mathrm{TS} / 1 / \mathrm{P}$ & B. circulans & 29 & 13 & 2.2 \\
\hline TS/1/S1/P1 & B. polymyxa & 28 & 12 & 2.3 \\
\hline $\mathrm{TS} / 1 / \mathrm{Q}$ & B. licheniformis & 28 & 5 & 5.6 \\
\hline $\mathrm{TS} / 1 / \mathrm{D}$ & Micrococcus varians & 12 & 4 & 3.0 \\
\hline $\mathrm{TD} / \mathrm{S} 2 / \mathrm{B} 1$ & B. megaterium & 24 & 12 & 2.0 \\
\hline $\mathrm{TD} / \mathrm{S} 2 / \mathrm{C} 3$ & B.pumilus & 29 & 5 & 5.8 \\
\hline TD/21-D & B. badius & 30 & 6 & 5.0 \\
\hline TD/21-D0 & B. alcalophilus & 29 & 17 & 1.7 \\
\hline TD/21-D1 & B. cereus & 21 & 7 & 3.0 \\
\hline TD/21-D3 & B. licheniformis & 17 & 5 & 3.4 \\
\hline TD/21-D8 & B. alvei & 18 & 4 & 3.0 \\
\hline
\end{tabular}


involved in soaking and bating of skin. The effluent discharging system of tanneries causes severe pollution to the water bodies. Although proteolytic enzymes are produced by many microorganisms, only a few bacteria and fungi could secret high quantity of proteases. Due to fast growth rate and easy of genetic manipulation bacterial proteases have been receiving good attention. Skim milk agar plate method was demonstrated to be effective in the screening of large number of proteolytic microorganisms (Wandersman et al. 1986, Lin et al. 1992). In the present study skim milk agar was used to screen the proteolytic bacterial isolates from tannery industries.

Alkaline protease production of 9 selected isolates is shown in the Table 4 . The alkaline protease production observed ranged between 7.1 and $119.3 \mathrm{U} / \mathrm{ml}$. The two isolates of B. pumilus (TS/1/S1/A3 and TD/S2/C3) showed maximum alkaline protease productions 119.3 and $94.8 \mathrm{U} / \mathrm{ml}$, respectively. There are numerous reports that different strains of Bacillus including B. alcalophilus, $B$. licheniformis, B. subtilis and B. thermobacter produce large amount alkaline protease (Kelly and Fogarty 1976, Shah et al. 1986, Manachini et al. 1988, Takii et al. 1990). Hameed et al. (1996) reported that Bacillus subtilis isolated from tannery waste produced an alkaline protease, when it was grown in a casein gelatin medium at $37^{\circ} \mathrm{C}$. Extracellular proteases are known to the most secretary enzyme of the genus Bacillus (Nishiya and Imanaka 1990). Hossain et al. (2004) studied the production of extracellular protease from Planococcus citreus.Three Bacillus strains showed high potential for alkaline protease activity (Genckal and Tari 2006). In the present study it was also observed that different species of Bacillus isolated from tannery industry could produce alkaline protease.

Table 4. Production of alkaline protease by nine selected bacterial strains.

\begin{tabular}{llc}
$\begin{array}{l}\text { Isolate } \\
\text { No. }\end{array}$ & Bacteria & $\begin{array}{c}\text { Enzyme production } \\
(\mathrm{U} / \mathrm{ml})\end{array}$ \\
\hline TS/1/S1/PS3 & Bacillus subtilis & 7.1 \\
TB/1/10 & B. circulans & 11.50 \\
TB/1/B4 & B. subtilis & 16.2 \\
TL/1/L/L3 & B. subtilis & 17.0 \\
TD/21-D & B. badius & 17.2 \\
TS/1/E & B. subtilis & 31.8 \\
TS/1/Q & B. licheniformis & 49.0 \\
TD/S2/C3 & B. pumilus & 94.8 \\
TS/1/S1/A3 & B. pumilus & 119.3 \\
\hline
\end{tabular}

The present findings showed that a good number of aerobic heterotrophic bacteria were associated with the leather processing industries. All the selected isolates showed different degree of proteolytic activities in the different protein 
based media. Some isolates could produce a considerable amount of alkaline protease and they could be good sources of alkaline proteases for commercial or industrial purposes.

\section{References}

Aunstrup K (1979) Production isolation and economics of extracellular enzymes. Appl. Biochem. Bioeng. 2: 27-68.

Bryan AH (1950) Manual of Methods for Pure Culture Study of Bacteria. Leaflet. I-X. McGraw Hill Book Co. Inc., New York.

Chu I-M, Lee C and Li T-S (1992) Production and degradation of alkaline protease in batch culture of Bacillus subtilis ATCC 14416. Enzyme Microbial Technol. 14: 755-761.

Collins CH and Lyne MP (1984) Microbiological Methods (5 $5^{\text {th }}$ edn.) Butterworth Co. (Publishers) Ltd., London. pp. 56-113.

Davighi D (1988) Keeping the environment clean. World Leather. 1: 29-32.

Eklund C and Lankford CE (1967) Laboratory Manual for General Microbiology. Prentice-Hall Inc., Englewood Cliffs, New Jersey. pp. 51-278.

Genckal H and Tari C (2006) Alkaline protease production from alkalophilic Bacillus sp. Isolated from natural habitats. Enzyme and Microbial Technology. 39: 703-710.

Greenberg AE, Connors JJ, Jenkins D and Franson MAH (1998) Standard methods for examination of water and wastewater (20 th $e d n$.). APHA, Washington DC.

Hameed A, Natt MA and Evans CS (1996) Production of alkaline protease by a new Bacillus subtilis isolate for use as bating enzyme in leather treatment. World. J. Microbiol. Biotechnol. 12: 289-291.

Horikoshi K (1971a) Production of alkaline enzymes by alkalophilic microorganism. Part I. Alkaline protease produced by Bacillus No. 221. Agric. Biol. Chem. 35: 1407-1414.

Hossain MT, Das F, Anwar MN (2004). Production of extracellular protease from Planococcus citreus. Bangladesh J Microbiol. 21(1): 22-24.

Kelly CT and Fogarty WM (1976) Microbial alkaline enzymes. Process Biochem. 11: 3-9.

Kreger A and Lockwood D (1981) Detection of extracellular toxin produced by Vibrio vulnificus. Infect. Immun. 33: 588-590.

Lin X, Lee CG, Casle ES and Shih JCH (1992) Purification and characterization of keratinase from feather degrading Bacillus licheniformis strain. Appl. Environ. Microbiol. 58: 3271-3275.

Manachini PL, Fortina MG and Parini C (1988) Thermostable alkaline protease produced by Bacillus thermoruber a new species of Bacillus. Appl. Microbiol. Biotechnol. 28: 409413.

Nishiya $\mathbf{Y}$ and Imanaka T (1990) Cloning and nucleotide sequence of Bacillus stearothermophilus neutral protease gene and its transcriptional activator gene. J. Bacteriol. 172: 4861-4869.

Peltier GL, Georgi CE and Lindgren LF (1959) Laboratory Manual for General Bacteriology (5 $5^{\text {th }}$ edn.) John Wiley and Sons. Inc., London.

Sharp MS and Lyles ST (1969) Laboratory instruction in biology of microorganisms. The C V Mosley Company, St. Louis. pp. 23-25. 
Shah DN, Shah VD, Nehete PN and Khotari RM (1986) Isolation of Bacillus licheniformis mutant from stable production profiles of alkaline protease. Biotechnol. Lett. 8: 103106.

Sneath PHA, Mair NS, Sharpe ME and Holt JG (Eds.) (986) Bergey's Manual of Systematic Bacteriology (9 $9^{\text {th }}$ edn., Vol. 2.) The Williams and Wilkins Co., Baltimore, USA. pp. 965-1599.

Takii Y, Kuriyama N and Suzuki Y (1990) Alkaline serine protease produced from citric acid by Bacillus alkalophilus sp. Sub sp. Halodurans KP 1239. Appl. Microbiol. Biotechnol. 34: 57-62.

Wandersman C, Andro T and Berthau Y (1986) Extracellular proteases in Erwinia chrysanthemum. Gen. Microbiol. 132: 899-906. 